\title{
Characterization of Physical, Gaseous, and Hydrologic Properties of Compacted Subsoil and its Effects on Growth and Transpiration of Two Maples Grown Under Greenhouse Conditions
}

\author{
Barbara A. Fair, James D. Metzger, and James Vent
}

\begin{abstract}
City foresters and horticulturists often seek trees suited for urban conditions. Two maples often used were selected to assess response to compacted soil: 'Armstrong' Freeman maple and 'Brandywine' red maple. Soil physical parameters were assessed to determine effects of high density on movement of gas and water. Rigid-walled lysimeters constructed from polyvinyl chloride pipe were filled with clay subsoil compacted to $1.64 \mathrm{~g} \cdot \mathrm{cm}^{-3}$ (MODEARTE-density) and $1.78 \mathrm{~g} \cdot \mathrm{cm}^{-3}$ (HIGH-density). Compaction decreased total porosity and saturated hydraulic conductivity. In addition, $\mathrm{CO}_{2}$ concentrations in compacted soil were 5-18 times higher than atmospheric concentrations, while $\mathrm{O}_{2}$ concentrations were similar to atmospheric levels despite density. $\mathrm{O}_{2}$ concentration played no real role in plant growth response to compaction. Trees growing in MODERATE-density soils had higher transpiration rates than trees growing in HIGH-density soils, although differences decreased over time. A high soil density did not affect caliper growth, but did reduce annual height growth, leaf area and dry weight, and stem dry weight, but responses varied over time and between species. Root dry weight and volume were unaffected by compaction, but root:shoot ratio was higher for trees growing in HIGH-density soils, which is expected as aboveground biomass is typically reduced by soil compaction.

Key Words. Acer $\times$ freemanii ‘Armstrong'; Acer rubrum 'Brandywine’; Bulk Density; Lysimeter; Saturated Hydraulic Conductivity; Soil Compaction; Transpiration; Urban Forestry.
\end{abstract}

Research consistently indicates soil compaction and aboveground and belowground woody plant biomass are negatively correlated, but plant response varies depending on intensity of compaction, soil water content, soil texture, and species (Alberty et al. 1984; Pan and Bassuk 1985; Day et al. 2000). Alberty et al. (1984) found no decrease in shoot and root dry weights due to high-bulkdensity sandy loam and loam soils for red-osier dogwood (Cornus sericea L.); however, there was significant reduction in growth of early forsythia (Forsythia ovata Nakai) in the same soils. Pan and Bassuk (1985) found root growth of tree-of-heaven (Ailanthus altissima Swingle) was restricted more in a sandy loam soil with a bulk density of $1.64 \mathrm{~g} \cdot \mathrm{cm}^{-3}$ than in mason sand (very fine aggregates) with a bulk density of $1.67 \mathrm{~g} \cdot \mathrm{cm}^{-3}$. Researchers have reported aboveground growth was affected more than root growth (Alberty et al. 1984; Masle and Passioura 1987; Cook et al. 1996; Montagu et al. 2001), although higher soil water content may alleviate some effects of compaction (Buttery et al. 1998; Day et al. 2000).

Urban soils pose many obstacles for sustained tree growth, including compaction, poor drainage, and poor physical properties. Accordingly, city foresters and landscape architects often select a bottomland species, for example sycamore (Platanus occidentalis L.), because of its demonstrated durability in city sites (Arnold 1980). Bottomland species may be successful because they are adapted to prolonged wet conditions, or they may be adapted to fluctuating conditions of wet and dry. Day et al. (2000) found silver maple (Acer saccharinum L.) was better able to penetrate wet high-density soils and performed better than flowering dogwood (Cornus florida L.). Flowering dogwood, an upland species, was not tolerant of wet or compacted soil conditions. Jackson (1997) found that in a high-density soil with low levels of $\mathrm{O}_{2}$ and poor drainage, some species produced high concentrations of ethylene. High ethylene can lead to the production of "ethylene" roots, which are short, thick and considerably branched (Kays et al. 1974; Morgan et al. 1993). Arborists have been taught that insufficient $\mathrm{O}_{2}$ in compacted soil is the primary restraint on tree growth. This may occur when soil is wet, but the relationship between oxygen and compaction is more complex. Recent studies indicate $\mathrm{O}_{2}$ concentration is not limited; rather, diffusion rates are weakly correlated with high densities (Boone and Veen 1994; Day et al. 1995; Murphy et al. 2000). Therefore, the following research was conducted to compare moderately and highly compacted soil with respect to $\mathrm{O}_{2}$ and ethylene content, physical properties, and the differential growth and transpiration of Acer $\times$ freemanii 'Armstrong' and Acer rubrum 'Brandywine' growing in these soils. To determine soil physical property changes, researchers measured saturated hydraulic conductivity, aeration, and soil gas concentrations (particularly $\mathrm{O}_{2}$ ) that may change in response to increased soil density. 


\section{MATERIALS AND METHODS}

\section{Tree Propagation and Growth}

In June 2001, $30 \mathrm{~cm}$ softwood cuttings of Acer $\times$ freemanii 'Armstrong' and Acer rubrum 'Brandywine' were collected from Klyn Nurseries, Inc., Perry, Ohio, U.S. 'Armstrong' is commonly used in street and landscape plantings throughout much of the northeast United States for its excellent autumn color and upright habit (Sydnor and Cowen 2000), and 'Brandywine', new to the market, has good autumn color, and is a small stature maple.

Cuttings were stripped to 3-4 terminal leaves with 2-4 internodes, trimmed to $20 \mathrm{~cm}$ length, kept moist, dipped in a talc formulation of $3000 \mathrm{ppm}$ indole-3-butyric acid (IBA) (OHP, Inc., Mainland, Pennsylvania, U.S.), and set in flats of soilless media (Metro-mix 510, Scotts Company, Marysville, Ohio, U.S.). Cuttings were placed in a continuous-mist house until rooted, and then potted in \#250 classic black pots impregnated with Root Right [Migratrol (active ingredient: cuprous chloride, $5.6 \% \mathrm{w} / \mathrm{w})$, Chambersburg, Pennsylvania, U.S.] using the same media. These were grown in a glass greenhouse with day and night temperature set points of $24^{\circ} \mathrm{C}$ and $21^{\circ} \mathrm{C}$, respectively. After three weeks, trees were fertilized once a week until leaf drop with $100 \mathrm{mg} \cdot \mathrm{L}^{-1} \mathrm{~N}$ from $20 \mathrm{~N}-4.3 \mathrm{P}-16.7 \mathrm{~K}$ water-soluble fertilizer (Peter's 20-10-20, O.M. Scotts Co., Marysville, Ohio, U.S.).

\section{Pot Construction}

Schedule 40 standard polyvinyl chloride (PVC) pipe was used to construct $30.5 \mathrm{~cm}$ inner diameter (ID) by $38 \mathrm{~cm}$ deep pots. PVC plastic sheeting $(0.3 \mathrm{~cm}$ thick) was glued to the bottom of the cut pipes using PVC glue. A $1.9 \mathrm{~cm}$ hole was drilled in the side of each pot, $3 \mathrm{~cm}$ from the base and a plastic pipefitting was glued into each hole. A 1.9 L plastic container (Gladware Products Company, Oakland, California, U.S.) was attached to each fitting to serve as the water reservoir, or nonweighing lysimeter. Containers were covered with $0.9 \mathrm{~mL}$ black plastic to prevent algal growth.

Subsoil (B horizon) used as the potting medium was obtained from Waterman Research and Education Facility in Columbus, Ohio, U.S. (Latitude $40.01^{\circ}$ and Longitude $-83.04^{\circ}$ ). The USDA Soil Conservation Service (SCS) classified the soil as Crosby silt loam, fine, mixed, mesic, aeric Ochraqualf type (McLoda and Parkinson 1980). In an undisturbed Crosby silt loam, the A horizon (down to $\sim 23 \mathrm{~cm}$ ) is characterized as a silt loam. Below $23 \mathrm{~cm}$, the $\mathrm{B}$ and $\mathrm{C}$ horizons would be clay loam or silty-clay loam (McLoda and Parkinson 1980).

Rocks/stones $>16 \mathrm{~cm}^{2}$ were removed and the soil was airdried for two weeks. Initial water content was then determined. Soil was pulverized and passed through a $2 \mathrm{~mm}$ round-hole sieve, and the Bouyoucos hydrometer method was used to determine soil texture, following methodology of Gee and Bauder (1986).

\section{Soil Compaction}

After air drying and texture assessment of the soil, water was added to increase gravimetric water content to $15 \%$. Soil was placed in an airtight container and allowed to equilibrate overnight, then weighed and added to pots in three $10.2 \mathrm{~cm}$ deep lifts (layers) to obtain target bulk densities of 1.4, 1.6, and 1.8 $\mathrm{g} \cdot \mathrm{cm}^{-3}$. These target bulk densities were selected because they were within the range found by many researchers to affect cer- tain characteristics of tree growth (Alberty et al. 1984; Pan and Bassuk 1985; Masle and Passioura 1987; Cook et al. 1996; Day et al. 2000; Montagu et al. 2001). A $4.5 \mathrm{~kg}$ sledgehammer was dropped from a height of about $0.3 \mathrm{~m}$ until each lift was at the correct depth to obtain the target bulk density. A soil knife (tool similar to a hand trowel) was used to score each lift to minimize formation of an interface between layers. Fourteen pots per target bulk density were prepared. Pots were watered thoroughly after compaction, covered tightly with plastic, and left to equilibrate for five days. One pot of each bulk density treatment was prepared as stated, but left fallow to assess evaporation loss from soil. These evaporation measurements were used to correct tree water use, thereby calculating tree transpiration.

Three gas ports were created in each of three pots of each of the three target bulk densities. Two $1.3 \mathrm{~cm}$ holes were drilled horizontally into the side of each of these nine PVC pots, passing through pot and soil, and one drilled vertically through soil only. Of the horizontal holes, one was drilled at 8 $\mathrm{cm}$ below the soil surface, the second at $20 \mathrm{~cm}$ below the soil surface, above the water table (saturated soil at bottom $5 \mathrm{~cm}$ of pot, created by lysimeter water level). The vertical hole was positioned at about $3 \mathrm{~cm}$ from the original root ball and approximately $7 \mathrm{~cm}$ from the edge of the pot. Plastic tubing, 0.5 cm ID (Fisher Scientific Company, Pittsburgh, Pennsylvania, U.S.) was inserted into each hole, a rubber sampling septum attached, and wrapped with aluminum foil to prevent drying. The first gas samples were taken 14 weeks after planting with sampling performed every two weeks thereafter to measure $\mathrm{O}_{2}$, $\mathrm{CO}_{2}$, and ethylene gas production. Gas analysis was conducted using a Model 436 Chromepack capillary gas chromatograph (Packard Instrument B.V, Zurich, Switzerland) set at $150^{\circ} \mathrm{C}$. A thermal conductivity detector was used for $\mathrm{O}_{2}, \mathrm{~N}_{2}$, and $\mathrm{CO}_{2}$. A flame ionization detector used for ethylene. Oxygen was analyzed on a $100 \mathrm{~cm} \times 0.6 \mathrm{~cm}$ column of molecular sieve $5 \mathrm{~A}$, and $\mathrm{CO}_{2}$ were separated on a $50 \mathrm{~cm} \times 0.6 \mathrm{~cm}$ Porapak T (Waters, Milford, Massachusetts, U.S.) column with a helium carrier gas at $20 \mathrm{~mL} \cdot \mathrm{min}^{-1}$. Ethylene was separated on an 80-100 mesh alumina (Coast Engineering, Redondo Beach, California, U.S.) column $(50 \mathrm{~cm} \times 0.6 \mathrm{~cm})$ with $\mathrm{N}$ carrier gas at $60 \mathrm{~mL} \cdot \mathrm{min}^{-1}$. Data were processed using a Chromatopac CR501 (Shimadzu Corporation, Kyoto, Japan). A $1 \mathrm{~mL}$ syringe was used to obtain the samples from each gas port.

\section{Tree Planting}

Twenty-one trees per cultivar were used; seven trees of each cultivar were planted under each of the three soil density treatments on March 22, 2002. The planting hole was made using a standard golf-green cup-cutter $(10.8 \mathrm{~cm})$. A soil knife was used to score the sides of the holes to minimize a potential soil interface. Once planted, pots were placed on greenhouse benches in a completely randomized design. Fabric discs were placed on the soil surface of each pot to minimize evaporation. Initial height and caliper were measured on this date. At the start of experiment, caliper ranged from 0.5 to $0.8 \mathrm{~cm}$ and 30 to $60 \mathrm{~cm}$ in height.

Tree Watering, Measurement, and Overwintering Water was supplied from the bottom by individual lysimeters that were filled to $1.5 \mathrm{~L}$ and replenished daily. The replenished volume was recorded as use for that period. Tran- 
spiration rate was calculated for the season and per unit leaf area. Transpiration measurements began May 31, 2002, and continued until leaf removal in October 2002. On October 19, 2002, final height and caliper were measured. All leaves were harvested from each tree to determine leaf area, after which leaves were placed in a drying oven at $82^{\circ} \mathrm{C}$ until dry.

Two trees were randomly selected from each cultivar for each soil compaction level for destructive harvest in October 2002. Stems were cut at top of root plate. Root volume was determined using a variation on the water-volume displacement method of Harrington et al. (1994) (Figure 1). A 10-L pipette cleaner (Nalgene $^{\circ}$, Rochester, New York, U.S.) was used as the water tub. It was filled with $6 \mathrm{~L}$ of water. A small hole was drilled $35 \mathrm{~cm}$ from the base of the pipette cleaner. A fitting was placed in the hole and $0.6 \mathrm{~cm}$ flexible plastic tubing was attached to the fitting. A $2 \mathrm{~mL}$ pipette, measuring to $0.01 \mathrm{~mL}$ was attached to the other end of the tubing. This was mounted alongside the pipette cleaner. The zero mark on the pipette was positioned level with the meniscus of the water in the tub. The tub and pipette were then calibrated by adding $1 \mathrm{~L}$ of water. This procedure was performed several times to ensure accurate calibration. Each time $1 \mathrm{~L}$ of water was added, the amount of water displaced was determined by counting the number of $0.01 \mathrm{~mL}$ increments the water level rose in the pipette. The volume of water displaced in the pipette by a known volume of water was used as a calibration factor to calculate root volume. Tree roots were soaked in water for approximately 15 minutes prior to volume determination. Each root system was gently dried, and then balled tightly to ensure the root system would float freely. The pipette was zeroed and the roots were dipped into the tub and, after the water came to rest, a reading was recorded. The root ball was suspended above the tub for approximately three minutes or until dripping had ceased. The roots were gently shaken to remove any excess water. Three readings were taken for each root system. Mean volumes were determined by multiplying the reading by the calibration factor. Stems and roots were placed in drying oven at $82^{\circ} \mathrm{C}$ until dry, about one week. Trees not harvested ( $\mathrm{n}=15$ of each species) were over-

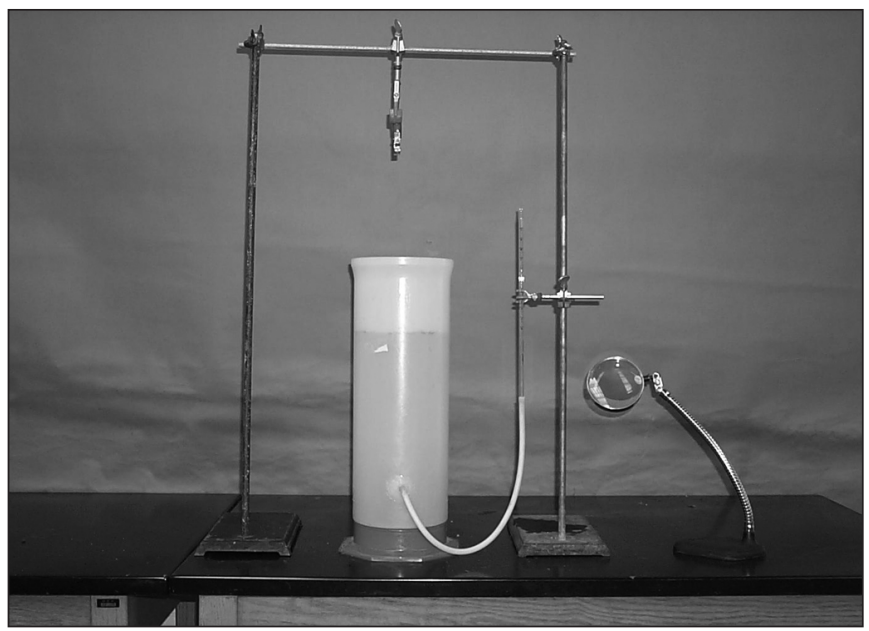

Figure 1. Adaptation of water displacement tub to assess root volume (Harrington et al. 1994). Roots were hung from center clip and allowed to float, unhindered in water. Water displaced was measured in pipette with use of magnifying glass. The system was calibrated three times before assessing root volumes, and each root system was assessed three times to obtain average volume. wintered in a minimum heat polyhouse with mean days/nights of $25^{\circ} \mathrm{C}$ and $4^{\circ} \mathrm{C}$, from November 15, 2002 through April 10, 2003.

On April 10, 2003, the overwintered trees were returned to randomlocations on greenhouse benches and the lysimeters recharged. Tree height and caliper were measured on this date. Transpiration measurements (collected as described earlier) began April 15, 2003.

On October 16, 2003, leaves were harvested from all remaining trees, leaf area measured, and dried as in the previous year. Final tree height and caliper were measured. A random sample of three trees from each cultivar and each soil compaction treatment was selected for destructive harvest. Root volume was determined as previously explained, as were stem and root dry weights. The remaining trees $(n=6$ of each species) were overwintered, as before, on November 22, 2003.

In the final year of the study, the remaining trees were returned to greenhouse benches on March 23, 2004. Tree height and caliper were measured on this date. Lysimeters were recharged and transpiration measurements began March 29, 2004.

As with before, leaves were harvested from all remaining trees on August 30, 2004. Height and caliper were measured on August 31, 2004. The remaining trees were destructively harvested and stem and root dry weights, and root volume were determined as described previously.

\section{Soil Measurements}

Two intact soil cores, $4.7 \mathrm{~cm}$ ID by $4.8 \mathrm{~cm}$ length were removed from each PVC pot in which a tree had been harvested, with an AMS Slide Hammer (Ben Meadows Co., Janesville, Wisconsin, U.S.). Excess soil was carefully trimmed from the ends of each core and cores were weighed. The excess soil was placed in metal tins, weighed and dried at $105^{\circ} \mathrm{C}$ for $\sim 24$ hours to determine the gravimetric water content (Blake and Hartge 1986). Upon completion of testing, cores were oven dried and weighed to calculate bulk density ( $\rho b)$. From $\rho b$ and known water gravimetric content, air-filled porosity (AP), total porosity, and void ratio were determined based on their mathematical relationship to $\rho b$ and water content for a known sample size. Saturated hydraulic conductivity (Ks) was measured in 2002 and 2003 for the intact cores following methodology of Klute and Dirksen (1986).

\section{Experimental Design and Data Analysis}

Pots and compaction treatments were arranged on greenhouse benches in a completely randomized design. Data were analyzed using SAS's general linear model procedures (PROC GLM), and correlations determined using PROC CORR to assess differences and trends between particular soil parameters and tree growth variables (SAS Inst., Inc., Cary, North Carolina, U.S.). Multiple comparisons were made using Tukey's honestly significant difference (HSD, $\alpha=0.05$ ). The Ks measurements were found to be well described by a log-normal distribution; the logarithmic-transformed Ks values were then analyzed using GLM and Tukey's HSD.

\section{RESULTS AND DISCUSSION}

\section{Soil Assessment}

The textural analysis classified the subsoil as a clay loam with $24 \%$ sand, $37 \%$ clay, and $39 \%$ silt. The target $\rho b$ levels were $1.4,1.6$, and $1.8 \mathrm{~g} \cdot \mathrm{cm}^{-3}$, respectively. The actual mean $\rho b$ val- 
ues for the three-year study were $1.64,1.78$, and $1.77 \mathrm{~g} \cdot \mathrm{cm}^{-3}$, respectively. For the most part, compaction efforts did result in bulk densities very close to the targeted values with the exception of the lowest target of $1.4 \mathrm{~g} \cdot \mathrm{cm}^{-3}$. The inability to obtain this lower density may have been due to soil textural type or unavoidable changes in gravimetric water content during the compaction process. Mechanical properties of clay soil, in particular sheer strength and pore space discontinuity, may prevent homogeneous soil compaction, despite use of consistent compaction techniques (Cook et al. 1996; Krümmelbein et al. 2010). No statistical differences were found between the $1.78 \mathrm{~g} \cdot \mathrm{cm}^{-3}$ and $1.77 \mathrm{~g} \cdot \mathrm{cm}^{-3}$ treatments for any soil parameter. Therefore, these values were combined and are presented as the "HIGHdensity" treatment. Henceforth, the $1.64 \mathrm{~g} \cdot \mathrm{cm}^{-3}$ treatment will be referred to as "MODERATE-density." This combination means there are twice as many observations for the HIGH-density" treatment than the MODERATE-density treatment (Table 1).

Table 1. Dry bulk density ( $\mathrm{b}$ ), aeration porosity, log-aeration porosity, total porosity, void ratio, saturated hydraulic conductivity (Ks), natural log-normalized saturated hydraulic conductivity (nLog(Ks)), and \% (v/v) volumetric water content for compacted soils averaged over three-year study.

\begin{tabular}{lll}
\hline & Soil treatment \\
\cline { 2 - 3 } $2002-2004$ mean soil variables & MODERATE & HIGH \\
\hline$\rho \mathrm{\rho b}\left(\mathrm{g} \cdot \mathrm{cm}^{-3}\right)$ & $1.64 \pm 0.02 \mathrm{~b}$ & $1.78 \pm 0.01 \mathrm{a}$ \\
Aeration porosity $(\%)$ & $13 \pm 1.2 \mathrm{~b}$ & $16 \pm 0.7 \mathrm{a}$ \\
Log-aeration porosity & $-0.94 \pm 0.04 \mathrm{~b}$ & $-0.84 \pm 0.02 \mathrm{a}$ \\
Total porosity $(\%)$ & $38 \pm 0.7 \mathrm{a}$ & $33 \pm 0.3 \mathrm{~b}$ \\
${\text { Void ratio }\left(\mathrm{m}^{3} \cdot \mathrm{m}^{-3}\right)}_{\mathrm{Ks}\left(\mathrm{cm} \cdot \mathrm{hr}^{-1}\right)^{\mathrm{y}}}$ & $0.62 \pm 0.02 \mathrm{a}$ & $0.50 \pm 0.01 \mathrm{~b}$ \\
nlog-Ks & $330.0 \pm 113.8 \mathrm{a}$ & $21.5 \pm 6.9 \mathrm{~b}$ \\
${\text { Volumetric water content }(\%, \mathrm{v} / \mathrm{v})^{\mathrm{x}}}^{\mathrm{x}}$ & $3.47 \pm 0.58 \mathrm{a}$ & $0.98 \pm 0.30 \mathrm{~b}$ \\
\hline
\end{tabular}

${ }^{\mathrm{z}}$ MODERATE $=$ mean bulk density for the three-year study of $1.64 \mathrm{~g} \cdot \mathrm{cm}^{-3}(\mathrm{n}=28$ soil samples), $\mathrm{HIGH}=$ mean bulk density for the three-year study of $1.77 \mathrm{~g} \cdot \mathrm{cm}^{-3}$ ( $\mathrm{n}=56$ samples).

y Saturated hydraulic conductivity (Ks) was measured in 2002 and 2003

${ }^{x}$ Volumetric water content was determined for each sample from gravimetric water content and bulk density measures; means \pm mean standard errors followed by different letters indicate a significant difference between soil treatments, at $P \leq$ 0.05 (Tukey's honestly significant difference test, HSD)

Mean $\rho b$ for the MODERATE-density treatment for the three-year study was significantly lower than the HIGH-density (Table 1). As would be expected, total porosity and void ratio values were highest for the MODERATE-density soil samples (Table 1). There was $25 \%$ more void space in the MODERATE-density treatment, with a concomitant greater potential for water and gas movement, and root extension. Total porosities were $38 \%$ and $33 \%$ for MODERATE and HIGHdensity treatments, respectively. These values are low, but within the 30\%-60\% range typical of mineral soils (Hillel 1998).

In the present study, air-filled porosity was $13 \%$ for MODERATE-density and $16 \%$ for HIGH-density soils (Table 1). The MODERATE-density treatment held 50\% more volumetric water content than the HIGH-density (Table 1), which may explain the lower air-filled porosity for the MODERATE-density soil. For both treatments, air-filled porosity was within the acceptable range for this textural type, indicating sufficient space for gas diffusion through the soil matrix (Greenwood 1971; Brady and Weil 2002).

Soil concentrations of $\mathrm{CO}_{2}$ were significantly higher in the MODERATE-density soils than the HIGH-density soils (Table
2). As expected, $\mathrm{CO}_{2}$ concentrations were 18 and 5 times higher than atmospheric concentrations in the MODERATE and HIGHdensity treatments, respectively. Oxygen and $\mathrm{N}_{2}$ levels were on average similar to atmospheric levels (Table 2), despite higher $\mathrm{O}_{2}$ levels in the HIGH-density treatment. The lower $\mathrm{O}_{2}$ and higher $\mathrm{CO}_{2}$ concentrations in the MODERATE-density soil were likely a result of significantly higher volumetric water content in these treatments when compared to the HIGH-density soil (Table 1). According to Scott (2000), $\mathrm{O}_{2}$ concentrations from $12 \%-20 \%$ by volume in soil gases, at soil depths of 30 to 150 $\mathrm{cm}$, are typical during the growing season in most mineral soils. Although there is no established critical limit for $\mathrm{O}_{2}$, concentrations $\leq 10 \%$ cause many tree roots to lose vigor (Kozlowski et al. 1991). Oxygen concentrations $<19 \%$ were not recorded for either compaction treatment in this study. Although $\mathrm{O}_{2}$ concentrations were somewhat lower for measurements taken at the lowest port location, these values were not significantly different from values sampled from other port locations (data not shown). Recent research suggests that neither $\mathrm{O}_{2}$ concentration nor diffusion rate are limiting to plants growing in highly compacted soils, although $\mathrm{O}_{2}$ concentration decreases and $\mathrm{CO}_{2}$ concentration increases with depth and density of the soil matrix (Shierlaw and Alston 1984; Day et al. 2000). Day et al. (2000) indicated a reduction in $\mathrm{O}_{2}$ diffusion rate was weakly correlated to soil water content, but there was no clear correlation between soil strength (resistance to root growth) and diffusion rate. Therefore, aeration porosity alone may not sufficiently describe the aeration status of a compacted soil, or the movement of $\mathrm{O}_{2}$ through that system.

Concentrations of ethylene in the samples were below detectable limits (data not shown); therefore, ethylene was not considered a factor in tree response. Additionally, there were no ethylene-induced architectural differences (Kays et al. 1974; Morgan et al. 1993) between trees growing in different soil treatments.

Both Ks and nlog-Ks values were 93\% higher in the MODERATE-density soil compared to the HIGH-density treatment (Table 1). This mirrors a field study also conducted in a clay loam soil where $98 \%$ difference in Ks was noted between compaction treatments (Fair et al. 2012). The differences found between compaction treatments were greater than those found by Coutadeur et al. (2002) at $40 \%$ or Gebhardt et al. (2009) at $60 \%$ in a clay loam.

Table 2. Comparison of mean percent $\mathrm{CO}_{2}, \mathrm{O}_{2}$, and $\mathrm{N}_{2}$ gas samples taken biweekly in 2002 and 2003 from MODERATEand HIGH-density soil treatments.

\begin{tabular}{llll}
\hline & \multicolumn{3}{l}{ Soil gas $^{\mathrm{z}}$} \\
\cline { 2 - 4 } Soil treatment $^{\mathrm{C}}$ & $\mathrm{CO}_{2}$ & $\mathrm{O}_{2}$ & $\mathrm{~N}_{2}$ \\
\hline MODERATE-density & $0.66 \pm 0.05 \mathrm{a}$ & $19.0 \pm 0.48 \mathrm{~b}$ & $80.4 \pm 0.56 \mathrm{a}$ \\
HIGH-density & $0.21 \pm 0.03 \mathrm{~b}$ & $21.2 \pm 0.10 \mathrm{a}$ & $78.7 \pm 0.09 \mathrm{~b}$ \\
\hline
\end{tabular}

${ }^{\mathrm{z}}$ Gases were sampled during growing season of 2002 and 2003 and represent the mean for the three sample ports per pot.

${ }^{y}$ MODERATE $=$ mean bulk density for three-year study of $1.64 \mathrm{~g} \cdot \mathrm{cm}^{-3}(\mathrm{n}=21$ gas samples), and HIGH= mean bulk density for the three-year study of $1.77 \mathrm{~g} \cdot \mathrm{cm}^{-3}$. $(\mathrm{n}=24$ gas samples); means \pm mean standard error followed by different letters indicate a significant difference between soil treatments, at $P \leq 0.05$.

\section{Tree Transpiration and Growth}

Table 3 summarizes the analysis of variance done on the following data. In 2002, trees growing in MODERATE-density soils had a $395 \%$ greater daily transpiration rate than trees growing in HIGH-density soils (Table 4). In 2003, the difference was $221 \%$, 
and in 2004, the difference had dropped to $4 \%$ (Table 4). Some of the differences in transpiration rate may have been due to higher volumetric water content and saturated hydraulic flow (greater water availability) in the MODERATE-density soils (Table 1). As saturated hydraulic flow increased, transpiration increased $\left(P<0.01, \mathrm{R}^{2}=0.73\right)$ for the MODERATE-density soils (Figure 2$)$. There was a weak linear relationship for the HIGH-density treatment, but, as expected, transpiration declined as $\mathrm{nLog}(\mathrm{Ks})$ declined (Figure 2). Kay et al. (2006) found a reduction in whole plant transpiration due to an increase in soil density and the change in water content in a clay type soil. Other research has found significant relationships between soil water content, soil texture, and soil density (Kay et al. 2006; Imhoff et al. 2010) In a study exploring the effects of compaction on transpiration of an entire forest community, Komatsu et al. (2007) also found a reduction in transpiration due to an increase in pedestrian traffic. In 2002, there was a significantly different response $(P=$ 0.06) between the maple species, with 'Brandywine' red maple transpiring 129\% more per day than 'Armstrong' Freeman maple (Table 4). In 2004, 'Brandywine' transpired $47 \%$ more per day than 'Armstrong' maple, which was significantly different at $P=0.10$ (Table 4). It is unlikely that species plays much of a factor in transpiration rates (Table 3). Transpiration based on leaf area $\left(\mathrm{mL} \cdot \mathrm{cm}^{-2}\right)$ was $200 \%$ greater for trees in MODERATE-

Table 3. Analysis of Variance (ANOVA) results showing significance for mean daily transpiration, daily transpiration per leaf area, leaf area, leaf dry weight, stem dry weight, caliper growth, height growth, root dry weight, root volume, and root:shoot ratio for two compaction treatments, two maple species, and three years, including interactions between soil treatment, species, and year.

\begin{tabular}{|c|c|c|c|c|c|c|}
\hline \multicolumn{7}{|c|}{ Analysis of Variance Results ${ }^{\mathrm{z}}$} \\
\hline & Species $^{y}$ & $\begin{array}{l}\text { Soil } \\
\text { treatment }\end{array}$ & Year & $\begin{array}{l}\text { Species soil } \\
\text { treatment }\end{array}$ & $\begin{array}{l}\text { Species } \\
\text { year* }\end{array}$ & $\begin{array}{l}\text { Soil treatment } \\
\text { year* }\end{array}$ \\
\hline \multicolumn{7}{|l|}{ Water use measures } \\
\hline Mean daily transpiration $(\mathrm{mL})$ & ns & $* * *$ & $* * *$ & ns & $* *$ & $* *$ \\
\hline $\begin{array}{l}\text { Mean daily transpiration per } \\
\text { leaf area }\left(\mathrm{mL} \cdot \mathrm{cm}^{2}\right)\end{array}$ & ns & $* *$ & $* * *$ & ns & ns & ns \\
\hline \multicolumn{7}{|l|}{ Biomass Measures } \\
\hline Leaf area $\left(\mathrm{cm}^{2}\right)$ & ns & $*$ & $* * *$ & ns & $* * *$ & ns \\
\hline Leaf dry weight (g) & ns & $*$ & $* * *$ & ns & $* * *$ & ns \\
\hline Stem dry weight (g) & $*$ & $* * *$ & $*$ & ns & ns & ns \\
\hline Caliper growth $\left(\mathrm{cm} \cdot \mathrm{yr}^{-1}\right)$ & ns & ns & $* * *$ & ns & ns & ns \\
\hline Height growth $\left(\mathrm{cm} \cdot \mathrm{yr}^{-1}\right)$ & $* * *$ & $*$ & $*$ & $*$ & $* *$ & ns \\
\hline Root dry weight $(\mathrm{g})$ & $*$ & ns & $* * *$ & ns & ns & ns \\
\hline Root volume $\left(\mathrm{cm}^{3}\right)$ & $* * *$ & ns & $* * *$ & ns & ns & ns \\
\hline Root:shoot (ratio) & $* *$ & $*$ & $* * *$ & ns & ns & $\mathrm{ns}$ \\
\hline
\end{tabular}

${ }^{\mathrm{z}}$ ANOVA results indicate that asterisks $(*, * *, * * *)$ represent statistical significance at $P \leq 0.05, P \leq 0.01, P \leq 0.001$ levels; ns indicates not significant.

${ }^{y}$ Species Acer $\times$ freemanii 'Armstrong', Armstrong Freeman maple and Acer rubrum 'Brandywine', Brandywine red maple; the species by soil treatment by year interaction is not shown as it was insignificant for all measurements.

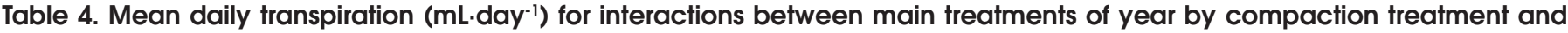
year by species.

\begin{tabular}{|c|c|c|c|}
\hline & Mean daily transpiration $\left(\mathrm{mL} \cdot\right.$ day $\left.^{-1}\right)$ & & \\
\hline Year by ${ }^{\mathrm{z}} /$ Soil treatment ${ }^{\mathrm{y}}$ & & Year by / Species ${ }^{x}$ & \\
\hline 2002 & & 2002 & \\
\hline $\begin{array}{l}\text { MODERATE-density } \\
(\mathrm{n}=14)\end{array}$ & $66.9 \pm 8.3 \mathrm{a}$ & $\begin{array}{l}\text { 'Armstrong' } \\
(\mathrm{n}=21)\end{array}$ & $19.0 \pm 7.4 \mathrm{~b}$ \\
\hline $\begin{array}{l}\text { HIGH-density } \\
(\mathrm{n}=28)\end{array}$ & $13.5 \pm 6.9 \mathrm{~b}$ & $\begin{array}{l}\text { 'Brandywine' } \\
(\mathrm{n}=21)\end{array}$ & $43.6 \pm 10.4 \mathrm{a}$ \\
\hline 2003 & & 2003 & \\
\hline $\begin{array}{l}\text { MODERATE-density } \\
(\mathrm{n}=10)\end{array}$ & $25.0 \pm 6.3 \mathrm{a}$ & $\begin{array}{l}\text { 'Armstrong' } \\
(\mathrm{n}=15)\end{array}$ & $11.4 \pm 6.1 \mathrm{a}$ \\
\hline $\begin{array}{l}\text { HIGH-density } \\
(\mathrm{n}=20)\end{array}$ & $7.8 \pm 3.2 b$ & $\begin{array}{l}\text { 'Brandywine' } \\
(\mathrm{n}=15)\end{array}$ & $15.6 \pm 2.8 \mathrm{a}$ \\
\hline 2004 & & 2004 & \\
\hline $\begin{array}{l}\text { MODERATE-density } \\
(\mathrm{n}=4)\end{array}$ & $56.9 \pm 11.4 \mathrm{a}$ & $\begin{array}{l}\text { 'Armstrong' } \\
(\mathrm{n}=6)\end{array}$ & $65.7 \pm 4.5 \mathrm{a}$ \\
\hline $\begin{array}{l}\text { HIGH-density } \\
(\mathrm{n}=8)\end{array}$ & $54.4 \pm 8.1 \mathrm{a}$ & $\begin{array}{l}\text { 'Brandywine' } \\
(\mathrm{n}=6)\end{array}$ & $44.8 \pm 10.7 b$ \\
\hline
\end{tabular}

${ }^{\mathrm{z}}$ Year study period was 2002, 2003, and 2004 .

${ }^{y}$ MODERATE $=$ mean bulk density for three-year study of $1.64 \mathrm{~g} \cdot \mathrm{cm}^{-3}, \mathrm{HIGH}=$ mean bulk density for the three-year study of $1.77 \mathrm{~g} \cdot \mathrm{cm}^{-3}$.

× Species were Acer $\times$ freemanii 'Armstrong', Armstrong Freeman maple, and Acer rubrum 'Brandywine', Brandywine red maple; sample sizes reflect the total number of trees available for sampling at the end of each year. At the end of 2002, 12 total trees were destructively harvested to determine stem weight and root growth. At the end of 2003, 18 total trees were destructively harvested, and at the end of the study, all remaining trees were harvested $(\mathrm{n}=12)$; Means \pm mean standard error followed by different letters indicate a significant difference between soil treatments at $P \leq 0.05$ for each year. Differences between species were found only at $P \leq 0.10(P=0.06$ in 2002 , and $P=0.10$ in 2004) 
density soils than for those growing in HIGH-density soils (Table 5). Transpiration per leaf area was significantly higher in 2004 when compared to values in either 2002 or 2003 (Table 5).

Increased soil density did not reduce annual caliper growth (data not shown). Trees growing in MODERATE-density soils were taller overall (data not shown). In the MODERATEdensity soil 'Armstrong' Freeman maple had greater height growth than the 'Brandywine' red maple; however, there was no significant difference between the cultivars in the HIGHdensity soils. Additionally, 'Armstrong' showed no decline in height growth from year to year, while 'Brandywine' slowed height growth in 2004 by $80 \%$ from the 2002 rate. While 'Bran-

Table 5. Mean daily transpiration per leaf area $\left(\mathrm{mL} \cdot \mathrm{cm}^{-2}\right)$ for year main treatment and soil treatment mean values averaged across 2002 to 2004.

\begin{tabular}{|c|c|c|c|}
\hline \multicolumn{4}{|c|}{ Mean daily transpiration per leaf area $\left(\mathrm{mL} \cdot \mathrm{cm}^{-2}\right)$} \\
\hline Year $^{2}$ & & Soil treatment ${ }^{y}$ & \\
\hline $\begin{array}{l}2002 \\
(n=42)\end{array}$ & $0.01 \pm 0.005 b$ & $\begin{array}{l}2002-2004 \\
\text { MODERATE-density } \\
(\mathrm{n}=14)\end{array}$ & $0.03 \pm 0.004 \mathrm{a}$ \\
\hline $\begin{array}{l}2003 \\
(n=30)\end{array}$ & $0.01 \pm 0.002 b$ & $\begin{array}{l}\text { HIGH-density } \\
(\mathrm{n}=28)\end{array}$ & $0.01 \pm 0.004 b$ \\
\hline $\begin{array}{l}2004 \\
(\mathrm{n}=12)\end{array}$ & $0.06 \pm 0.009 \mathrm{a}$ & & \\
\hline
\end{tabular}

${ }^{z}$ Year study period was for 2002, 2003, and 2004.

${ }^{y}$ MODERATE $=$ mean bulk density for three-year study of $1.64 \mathrm{~g} \cdot \mathrm{cm}^{-3}, \mathrm{HIGH}=$ mean bulk density for the three-year study of $1.77 \mathrm{~g} \cdot \mathrm{cm}^{-3}$; sample sizes for each year or compaction treatment are indicated in parenthesis; means \pm mean standard error followed by different letters indicate a significant differences between mean daily transpiration per leaf area rate between years or soil treatments averaged across the three-year study period at $P \leq 0.05$.

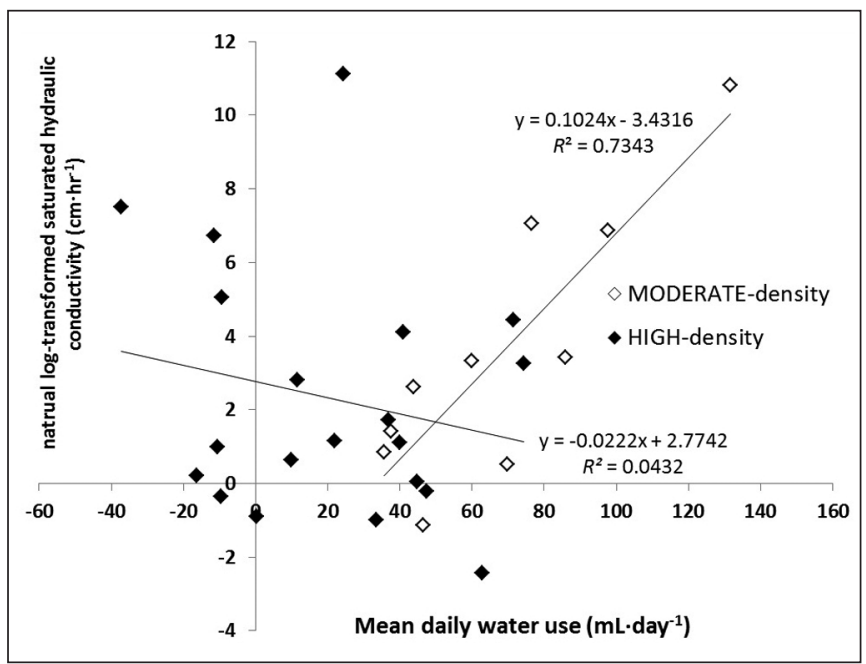

Figure 2. Allometric relationship between mean tree transpiration and natural-log transformed saturated hydraulic conductivity; correlation generated with linear best-fit model with line equations and $\mathbf{R}^{2}$ values shown for each soil treatment.

MODERATE = mean bulk density for the three-year study of $1.64 \mathrm{~g} \cdot \mathrm{cm}^{-3}(n=24$ soil samples and $n=28$ transpiration measurements). HIGH = mean bulk density for the three-year study of $1.77 \mathrm{~g} \cdot \mathrm{cm}^{-3}(\mathrm{n}=\mathbf{4 8}$ soil samples and $n=42$ transpiration measurements). Each data point represents a mean of two sample soil cores taken from each lysimeter and the corresponding tree transpiration for the three-year study. dywine' was relatively unaffected by a higher soil density, 'Armstrong' trees decreased height growth by 52\% (Table 6). These findings are somewhat contrary to results from fieldwork that found significant reductions in caliper growth but no effect on height or height growth of red and Freeman maple cultivars due to an increase of soil density (Fair et al. 2012). The different findings may be due to tree size at planting between the two experiments. Trees used in the present lysimeter study ranged from 0.5 to $0.9 \mathrm{~cm}$ caliper at planting, and trees from Fair et al. (2012) ranged between 0.7 and $2.3 \mathrm{~cm}$ at planting. Additionally, many researchers consider the mean $\rho b$ of the MODERATE-density treatment as growth limiting for woody plants (Alberty et al. 1984; Day and Bassuk 1994; Day et al. 1995).

Trees growing in MODERATE-density soils had greater leaf area, leaf dry weight (dw), and stem dw (Table 6; Table 7) than those growing in the HIGH-density soil, similar to other reports in the literature (Masle and Passioura 1987; Cook et al. 1996; Montagu et al. 2001). Both leaf area and leaf dw values for 'Armstrong', showed no significant difference across the study years, but there was a $31 \%$ reduction in both leaf area and leaf dw, between trees grown in the two soil treatments (Table 6). Both leaf values for 'Brandywine' however, showed significant differences from year to year (Table 6). Leaf area decreased by $60 \%$ and leaf dw decreased by 52\% between 2002 and 2004. 'Armstrong' Freeman maple had significantly larger stem dw than 'Brandywine' red maple (Table 7). Additionally, both cultivars had an increase in stem dry weight from 2002 to 2004 of 54\% (Table 7).

Root dry weight and root volume were unaffected by soil compaction; however, root:shoot ratio was significantly higher for trees growing in the HIGH-density soils (Table 7). Another compaction study found higher density soils led to reduced root $\mathrm{dw}$ and reduction of fine-root surface area (Cook et al. 1996). Further studies found that reductions in root dw, due to compaction, were insignificant or aboveground growth was affected to a greater magnitude than root growth (Alberty et al. 1984; Masle and Passioura 1987; Andrade et al. 1993; Cook et al. 1996; Montagu et al. 2001). As in this study, root:shoot ratio has been found to increase with increased compaction, because shoot dw values are likely to be lower (Andrade et al. 1993; Hussain et al. 1999). One reason the present study may have found few differences in root systems due to an increase in compaction may be that roots were able to make use of the heterogeneity of soil aggregates and grow into pore spaces, despite uniform compaction efforts. Roots were also in contact with the water table, but did not grow into this saturated area. Capillary rise and water movement through unsaturated flow may have provided sufficient water to the roots (Boone and Veen 1994), but been insufficient to supply enough water to maintain aboveground growth of trees growing in the HIGH-density soil (Table 4; Table 5). Soils with a volumetric water content of $15 \%$ (Kay et al. 2006) may permit satisfactory root growth allowing trees to tolerate high bulk densities (Day et al. 2000).

There were mixed results when comparing species growth response to soil density. 'Brandywine' red maple had significantly higher mean leaf area and leaf dw in 2002 than 'Armstrong' (Table 6), which may account for higher mean transpiration rates (Table 4). 'Brandywine' also had larger stem $\mathrm{dw}$, root volume, and root:shoot ratio (Tables 7). 'Armstrong' was taller (data not shown) and height growth increased faster than 'Brandywine' but only in MODERATE-density soils 
(Table 6). Both species had reduced height due to an increase in soil compaction. Variations in height growth may be due to the columnar growth habit of 'Armstrong' Freeman maple as compared to the round habit and smaller stature of 'Brandywine' red maple. Unlike most studies that assess species variations, there were very few differences between these maples.
The field research done in conjunction with this greenhouse study indicates that cultivar differences are critical when explaining the effects of compaction on tree growth (Fair et al. 2012). These results suggest that in similarly compacted clay loam soils, arborists and urban foresters might get somewhat better performance from 'Brandywine' than from 'Armstrong'.

Table 6. Mean annual height growth, leaf area, and dry weight measurements for interactions between year by species and for species by soil treatment.

\begin{tabular}{|c|c|c|c|}
\hline & \multicolumn{3}{|l|}{ Biomass measure } \\
\hline & Height growth $\left(\mathrm{cm} \cdot \mathrm{y}^{-1}\right)$ & Leaf area $\left(\mathrm{cm}^{2}\right)$ & Leaf dw $(\mathrm{g})$ \\
\hline \multicolumn{4}{|l|}{ Year by species ${ }^{z y}$} \\
\hline \multicolumn{4}{|l|}{$2002(n=21)$} \\
\hline 'Armstrong' & $27.0 \pm 3.8 \mathrm{a} \mathrm{(a)}$ & $1167.4 \pm 85.2 \mathrm{~b}(\mathrm{a})$ & $9.2 \pm 0.6 \mathrm{~b}(\mathrm{a})$ \\
\hline 'Brandywine' & $30.1 \pm 4.2 \mathrm{a}[\mathrm{a}]$ & $2150.9 \pm 137.1 \mathrm{a}[\mathrm{a}]$ & $13.5 \pm 0.9 \mathrm{a}[\mathrm{a}]$ \\
\hline \multicolumn{4}{|l|}{$2003(\mathrm{n}=15)$} \\
\hline 'Armstrong' & $27.3 \pm 4.4$ a (a) & $1429.2 \pm 231.4 \mathrm{a} \mathrm{(a)}$ & $10.3 \pm 1.5 \mathrm{a}(\mathrm{a})$ \\
\hline 'Brandywine' & $11.6 \pm 2.5 \mathrm{~b}[\mathrm{~b}]$ & $1411.1 \pm 105.9 \mathrm{a}[\mathrm{b}]$ & $9.0 \pm 0.7 \mathrm{a}[\mathrm{b}]$ \\
\hline \multicolumn{4}{|l|}{$2004(\mathrm{n}=6)$} \\
\hline 'Armstrong' & $27.8 \pm 5.7$ a (a) & $1041.1 \pm 88.3 \mathrm{a}(\mathrm{a})$ & $8.0 \pm 0.6 \mathrm{a}(\mathrm{a})$ \\
\hline 'Brandywine' & $6.1 \pm 4.2 \mathrm{~b}[\mathrm{~b}]$ & $860.3 \pm 50.6 \mathrm{a}[\mathrm{c}]$ & $6.5 \pm 0.4 \mathrm{a}[\mathrm{c}]$ \\
\hline \multicolumn{4}{|l|}{ Species by soil treatment ${ }^{x}$} \\
\hline \multicolumn{4}{|l|}{ 'Armstrong' } \\
\hline MODERATE-density $(n=14)$ & $40.1 \pm 4.3 \mathrm{a} \mathrm{(a)}$ & $1577.0 \pm 241.0 \mathrm{a}(\mathrm{a})$ & $11.8 \pm 1.5 \mathrm{a}(\mathrm{a})$ \\
\hline HIGH-density $(\mathrm{n}=28)$ & $20.8 \pm 2.4 \mathrm{~b}[\mathrm{a}]$ & $1075.8 \pm 61.9 \mathrm{~b}[\mathrm{~b}]$ & $8.2 \pm 0.4 \mathrm{~b}[\mathrm{~b}]$ \\
\hline \multicolumn{4}{|l|}{ 'Brandywine' } \\
\hline MODERATE-density $(n=14)$ & $21.8 \pm 4.7 \mathrm{a}(\mathrm{b})$ & $1972.0 \pm 224.2 \mathrm{a}(\mathrm{a})$ & $12.3 \pm 1.5 \mathrm{a}(\mathrm{a})$ \\
\hline
\end{tabular}

${ }^{\mathrm{z}}$ Year study period was 2002, 2003, and 2004 .

y Species were Acer $\times$ freemanii 'Armstrong', Armstrong Freeman maple, and Acer rubrum 'Brandywine', Brandywine red maple; means \pm mean standard error followed by different letters indicate a significant difference between treatments, at $P \leq 0.05$ (Tukey's honestly significant difference test, HSD); values in parentheses indicate differences within a single species but between year or soil treatment, and means in brackets indicate differences within either a single year and between species, or a single species between soil treatments.

${ }^{\mathrm{x}}$ MODERATE $=$ mean bulk density of $1.64 \mathrm{~g} \cdot \mathrm{cm}^{-3}(\mathrm{n}=24), \mathrm{HIGH}=$ mean bulk density of $1.77 \mathrm{~g} \cdot \mathrm{cm}^{-3}(\mathrm{n}=48)$ averaged across the three-year study.

Table 7. Mean stem dry weight, root dry weight, root volume, and root:shoot ratio are indicated for each soil treatment, each maple cultivar, and each year.

\begin{tabular}{|c|c|c|c|c|}
\hline & \multicolumn{4}{|l|}{ Biomass measure } \\
\hline & Stem dry wt (g) & Root dry wt (g) & Root volume $\left(\mathrm{cm}^{3}\right)$ & Root:shoot (ratio) \\
\hline \multicolumn{5}{|l|}{ Soil treatment ${ }^{z}$} \\
\hline $\begin{array}{l}\text { MODERATE-density } \\
(\mathrm{n}=14)\end{array}$ & $23.7 \pm 2.4 \mathrm{a}$ & $45.7 \pm 6.4 \mathrm{a}$ & $100.1 \pm 15.2 \mathrm{a}$ & $1.3 \pm 0.13 b$ \\
\hline $\begin{array}{l}\text { HIGH-density } \\
(\mathrm{n}=28)\end{array}$ & $15.2 \pm 1.2 \mathrm{~b}$ & $36.7 \pm 3.8 \mathrm{a}$ & $78.6 \pm 9.6 \mathrm{a}$ & $1.5 \pm 0.11 \mathrm{a}$ \\
\hline \multicolumn{5}{|l|}{ Species $^{y}$} \\
\hline $\begin{array}{l}\text { 'Armstrong' Freeman maple } \\
(\mathrm{n}=21)\end{array}$ & $15.3 \pm 1.9 b$ & $32.7 \pm 4.5 \mathrm{a}$ & $64.5 \pm 10.1 b$ & $1.3 \pm 0.10 \mathrm{~b}$ \\
\hline $\begin{array}{l}\text { 'Brandywine' red maple } \\
(\mathrm{n}=21)\end{array}$ & $20.8 \pm 1.4 \mathrm{a}$ & $46.7 \pm 4.5 \mathrm{a}$ & $107.0 \pm 11.2 \mathrm{a}$ & $1.5 \pm 0.14 \mathrm{a}$ \\
\hline \multicolumn{5}{|l|}{ Year ${ }^{x}$} \\
\hline $2002(\mathrm{n}=12)$ & $13.6 \pm 1.9 \mathrm{~b}$ & $18.4 \pm 2.6 \mathrm{~b}$ & $67.9 \pm 12.8 b$ & $0.72 \pm 0.04 \mathrm{c}$ \\
\hline $2003(\mathrm{n}=18)$ & $19.0 \pm 2.2 \mathrm{a}$ & $43.5 \pm 5.0 \mathrm{a}$ & $108.3 \pm 15.4 \mathrm{a}$ & $1.49 \pm 0.07 \mathrm{~b}$ \\
\hline $2004(\mathrm{n}=12)$ & $20.9 \pm 1.9 a$ & $55.3 \pm 3.9 a$ & $142.7 \pm 10.6 \mathrm{a}$ & $1.98 \pm 0.11 \mathrm{a}$ \\
\hline
\end{tabular}

${ }^{\mathrm{z}}$ MODERATE $=$ mean bulk density of $1.64 \mathrm{~g} \cdot \mathrm{cm}^{-3}(\mathrm{n}=24), \mathrm{HIGH}=$ mean bulk density for the three-year study of $1.77 \mathrm{~g} \cdot \mathrm{cm}^{-3}(\mathrm{n}=48)$.

${ }^{y}$ Species Acer $\times$ freemanii 'Armstrong', Armstrong Freeman maple, and Acer rubrum 'Brandywine', Brandywine red maple; means \pm mean standard error followed by different letters indicate a significant difference between soil treatments, species, or year at $P \leq 0.05$.

x Year study period was 2002, 2003, and 2004. 


\section{CONCLUSIONS}

Contrary to the long-held belief that compaction reduces $\mathrm{O}_{2}$, levels were well within the acceptable range despite high $\rho b$. Plant growth was limited by compaction, but most likely due to the reduced hydraulic flow that led to reduced transpiration, rather than low $\mathrm{O}_{2}$ levels. Under otherwise consistent environmental conditions, trees will transpire more and be more efficient in converting water into biomass in lower density soils due to higher hydraulic flow rates. Therefore, in addition to minimizing compaction or alleviating it when preparing sites for tree planting, it is important to maintain sufficient available water for plant use. It is also important to investigate cultivar performance during the planning phase of any planting project. There are often noteworthy differences in how different species perform in compacted soil types, even at the cultivar level, and therefore more research would provide urban foresters greater guidance during the selection process.

Acknowledgments. This research was supported by funds from Kiplinger Endowment for Floriculture, a gift from the Ohio Nursery and Landscape Association (ONLA). Salary and additional research support provided by State and Federal funds appropriated to the Ohio Agricultural Research and Development Center, The Ohio State University. This paper is based on a portion of a dissertation submitted by B. Fair in partial fulfillment of the requirements for the Ph.D. degree in horticulture. We would also like to thank Dr. William Swallow (NCSU) for his invaluable statistical expertise.

\section{LITERATURE CITED}

Alberty, C.A., H.M. Pellett, and D.H. Taylor. 1984. Characterization of soil compaction at construction sites and woody plant response. Journal of Environmental Horticulture 2:48-53.

Arnold, H.F. 1980. Choice of Type. In: Trees in Urban Design. Litton Educational Publishing, Inc. Van Nostrand Reinhold Co. New York, New York, U.S. pp. 99-100.

Andrade, A., D.W. Wolfe, and E. Fereres. 1993. Leaf expansion, photosynthesis, and water relations of sunflower plants grown on compacted soil. Plant and Soil 149:175-184.

Blake, G.R., and K.H. Hartge. 1986. Bulk density. In: A. Klute (Ed.). Methods of Soil Analysis, Part 1, Physical and Mineralogical Methods, 2nd edition. ASA-Soil Science Society of America, Monograph 9. Madison, Wisconsin, U.S. pp. 364-367.

Boone, F.R., and B.W. Veen. 1994. Crop responses to soil compaction. In: B.D. Soane and C. van Ouwerkerk (Eds.). Soil compaction in crop production. Elsevier, Amsterdam. Ch. 11. pp. 237-264.

Brady, N.C., and R.R. Weil. 2002. In the Nature and Properties of Soils. 13th edition. Pearson Education, Inc., Upper Saddle River, New Jersey, U.S. pp. 121-218.

Buttery, B.R., C.S. Tan, C.F. Drury, S.J. Park, R.J. Armstrong, and K.Y. Park. 1998. The effects of soil compaction, soil moisture and soil type on growth and nodulation of soybean and common bean. Canadian Journal of Plant Science 78:571-576.

Cook, A., C.A. Marriott, W. Steel, and C.E. Mullins. 1996. Effects of soil mechanical impedance on root and shoot growth of Lolium perenne L., Agrostis capillaris and Trifoloium repens L. Journal of Experimental Botany 47:1075-1084.

Coutadeur, C., Y. Coquet, and J. Roger-Estrade. 2002. Variation of hydraulic conductivity in a tilled soil. European Journal of Soil Science 53:619-628.

Day S.D., and N.L. Bassuk. 1994. A review of the effects of soil compaction and amelioration treatments on landscape trees. Journal of Arboriculture 20:9-16.
Day S.D., N.L. Bassuk, and H. van Es. 1995. Effects of four compaction remediation methods for landscape trees on soil aeration, mechanical impedance and tree establishment. Journal of Environmental Horticulture 13(2):64-71

Day, S.D., J.R. Seiler, and N. Persaud. 2000. A comparison of root growth dynamics of silver maple and flowering dogwood in compacted soil at differing soil water contents. Tree Physiology 20:257-263.

Fair, B.A., J.D. Metzger, and J. Vent. 2012. Response of eight maple cultivars (Acer spp.) to soil compaction and effects of two rates of pre-plant nitrogen on tree establishment and aboveground growth. Arboriculture \& Urban Forestry 38(2):64-74.

Gebhardt, S.H., Fleige, and R. Horn. 2009. Effect of compaction on pore functions of soils in a Saalean moraine landscape in north Germany. Journal of Plant Nutrition and Soil Science 172:688-695.

Gee, G.W., and J.W. Bauder. 1986. Particle-size analysis. In: A. Klute (Ed.). Methods of Soil Analysis, Part 1, Physical and Mineralogical Methods. 2nd edition. ASA-Soil Science Society of America. Monograph 9. Madison, Wisconsin, U.S. pp. 383-411.

Greenwood, D.J. 1971. Soil aeration and plant growth. Reports on the progress of applied chemistry, London, Society of Chemical Industry $55: 423-431$

Harrington, J.T., J.G. Mexal, and J.T Fisher. 1994. Volume displacement provides a quick and accurate way to quantify new root production. Tree Planter's Notes. Fall. 45:121-124.

Hillel, D. 1998. Fundamentals of Soil Physics. Academic Press, Inc., New York, New York, p. 11.

Hussain, A., C.R. Black, I.B. Taylor, B.J. Mulholland, and J.A. Roberts. 1999. Novel approaches for examining the effects of differential soil compaction on xylem sap abscisic acid concentration, stomatal conductance and growth in barley (Hordeum vulgare L.). Plant, Cell and Environment 22:1377-1388.

Imhoff, S., B.D. Kay, A. Pires da Silva, and M.A. Hajabbasi. 2010. Evaluating responses of maize (Zea mays L.) to soil physical conditions using a boundary line approach. Soil \& Tillage Research 106:303-310.

Jackson, M.B. 1997. Hormones from roots as signals for the shoots of stressed plants. Trends Plant Science 2:22-28.

Kay, B.D., M.A. Hajabbasi, J.Ying, and M. Follenaar. 2006. Optimum versus non-limiting water content for root growth, biomass accumulation, gas exchange and the rate of development of maize (Zea mays L.). Soil \& Tillage Research 88:42-54.

Kays, S.J., C.W. Nicklow, and D.H. Simons. 1974. Ethylene in relation to the response of roots to physical impedance. Plant and Soil 40:565-571.

Klute, A., and C. Dirksen. 1986. Hydraulic conductivity and diffusivity: Laboratory methods. In: A. Klute (Ed.). Methods of Soil Analysis, Part 1, Physical and Mineralogical Methods. 2nd edition. ASA-Soil Science Society of America Monograph 9. Madison, Wisconsin, U.S. pp. 687-733.

Komatsu, H., A. Katayana, S. Hirose, A. Kume, N. Higashi, S. Ogawa, and K. Otsuki. 2007. Reduction in soil water availability and tree transpiration in a forest with pedestrian trampling. Agricultural and Forest Meteorology 146:107-114.

Kozlowski, T.T., P.J. Kramer, and S.G. Pallardy. 1991. Soil aeration, compaction, and flooding. In: The Physiological Ecology of Woody Plants. H.A. Mooney (Ed.). Academic Press, Inc. San Diego, California, U.S. pp. 303-307.

Krümmelbein, J., R. Horn, T. Raab, O. Beus, and R.F. Hühl. 2010. Soil physical parameters of a recently established agricultural recultivation site after brown coal mining in East Germany. Soil \& Tillage Research 111:19-25. 
Masle, J., and J.B. Passioura. 1987. The effect of soil strength on the growth of young wheat plants. Australian Journal of Plant Physiology 14:643-656.

McLoda, N.A., and R.J. Parkinson. 1980. Soil Survey of Franklin County, Ohio. U.S. Dept. Agr., Soil Conservation Service, Columbus Ohio, U.S. pp. 89-90.

Montagu, K.D., J.P. Conroy, and B.J. Atwell. 2001. The position of localized soil compaction determines root and subsequent shoot growth responses. Journal of Experimental Botany 52:2127-2133.

Morgan, P.W., J.L. Sarquis, C. He, W.R. Jordan, and M.C. Drew. 1993. Regulation of ethylene biosynthesis in maize root responses to stress. In: J.C. Pech, A. Latcheand, and C. Balague (Eds.). Cellular and Molecular Aspects of the Plant Hormone Ethylene. Kluwer Academic Publishers, Dordrecht, The Netherlands, pp. 232-237.

Murphy, J.A., S.L. Murphy, and H. Samaranayake. 2000. Soil physical constraints and plant growth interactions. In: R.E. Wilkinson (Ed.). Plant-Environment Interactions. 2nd edition. Marcel Dekker, Inc., New York, U.S. pp. 387-406.

Pan, E., and N.L. Bassuk. 1985. Effects of soil type and compaction on the growth of Ailanthus altissima seedlings. Journal of Environmental Horticulture 3:161-167.

Scott, H.D. 2000. Soil Physics, Agricultural and Environmental Applications. Iowa State Univ. Press. Ames, Iowa, U.S. pp. 24.

Shierlaw J., and A.M. Alston. 1984. Effects of soil compaction on root growth and uptake of phosphorous. Plant and Soil 77:15-28.

Sydnor, T.D., and W.F. Cowen. 2000. Ohio Trees. Ohio State University Extension. pp. 166-167.

Barbara A. Fair (corresponding author)

North Carolina State University

Department of Horticultural Science

Campus Box 7609

Raleigh, North Carolina 27695-7609, U.S.

The Ohio State University

Horticulture and Crop Science

2021 Coffey Road

Columbus, Ohio 43210, U.S.

James D. Metzger

The Ohio State University

Horticulture and Crop Science

2021 Coffey Road

Columbus, Ohio 43210, U.S.

James Vent

The Ohio State University

Horticulture and Crop Science

2021 Coffey Road

Columbus, Ohio 43210, U.S.
Zusammenfassung. Stadtförster und Gärtner suchen oft nach geeigneten Baumarten für die Bedingungen in der Stadt. Zwei oft verwendete Ahorne wurden ausgewählt, um ihre Reaktion auf verdichtete Böden zu untersuchen: Acer x freemanii „Armstrong“ und Acer rubrum „Brandywine“. Um die Auswirkungen von hoher Dichte auf den Gasund Wasseraustausch zu untersuchen, wurden die physikalischen Bodenparameter erhoben. Lysimeter mit dichten Aussenwänden aus Polyvinylchlorid-Rohr wurden mit tonigem Unterboden verfüllt und mit 1,64 $\mathrm{g} \mathrm{cm}^{-3}$ (mittlere Dichte) und $1,78 \mathrm{~g} \mathrm{~cm}^{-3}$ (hohe Dichte) verdichtet. Die Verdichtung reduzierte die totale Porösität und sättigte die hydraulische Leitfähigkeit. Auch die $\mathrm{CO}_{2}$-Konzentration in verdichteten Böden war 8-15mal höher als die atmosphärischen Konzentrationen, während die $\mathrm{O}_{2}$-Konzentrationen ähnlich wie die atmosphärischen Konzentrationen unabhängig von der Dichte lagen. Die $\mathrm{O}_{2}$-Konzentrationen spielten keine wirkliche Rolle bei der reaktion der Pflanzen auf Verdichtung. Bäume, die in moderat verdichteten Böden wuchsen, hatten höhere Transpirationsraten als die Bäume in hoch verdichteten Böden, obwohl die Unterschiede mit der Zeit abnahmen. Eine hohe Bodenverdichtung beeinträchtigte nicht den Umfangzuwachs, aber die jährliche Wachstumsrate, Blattfläche und -trockengewicht sowie Stammtrockengewicht, aber die Ergebnisse variierten über die Zeit und zwischen den Arten. Das Wurzeltrockengewicht und Volumen wurde durch die Verdichtung nicht beeinflusst, aber das Wurzel:Trieb-Verhältnis war höher bei Böden in hoch verdichteten Böden, was zu erwarten war, da die oberirdische Biomasse typischerweise durch Bodenverdichtung reduziert wurde.

Resumen. Horticultores y silvicultores de la ciudad a menudo buscan árboles adecuados para las condiciones urbanas. Dos maples usados con frecuencia se seleccionaron para evaluar la respuesta al suelo compactado: arce 'Armstrong' Freeman y arce rojo 'Brandywine'. Parámetros físicos de suelos fueron evaluados para determinar los efectos de alta densidad en el movimiento de gas y agua. Lisímetros de paredes rígidas fueron construidos a partir de tubería de cloruro de polivinilo, llenos de

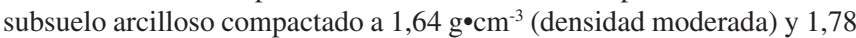
$\mathrm{g} \bullet \mathrm{cm}^{-3}$ (densidad alta). La compactación disminuyó la porosidad total y la conductividad hidráulica saturada. Además, las concentraciones de $\mathrm{CO}_{2}$ en suelo compactado fueron 5-18 veces mayores que las concentraciones atmosféricas, mientras que las concentraciones de $\mathrm{O}_{2}$ eran similares a los niveles atmosféricos a pesar de la densidad. La concentración de $\mathrm{O}_{2}$ no desempeñó ningún papel real en la respuesta de crecimiento de la planta a la compactación. Los árboles que crecen en suelos de moderada densidad tuvieron tasas más altas de transpiración que los árboles que crecen en suelos de alta densidad, aunque las diferencias disminuyeron con el tiempo. Una densidad de suelo elevada no afectó el crecimiento del diámetro, pero hizo reducir el crecimiento anual de la altura, área foliar y peso seco y tallo seco, pero las respuestas variaron con el tiempo y entre especies. El volumen y peso seco de raíz fueron afectadas por la compactación, pero la relación de raíz: brote fue superior para árboles que crecen en suelos de alta densidad, lo cual es esperado como la biomasa aérea normalmente reduce la compactación del suelo. 